\title{
IMPACT OF SELF-CONTROL ON ANXIETY AND PERCEIVED STRESS DURING A TOURISM, MOUNTAINEERING AND ORIENTEERING COURSE
}

\author{
Galina Domuschieva-Rogleva, \\ Nikolai Panaiotov \& Michail Georgiev \\ National Sports Academy "Vassil Levski”, Sofia, Bulgaria
}

\begin{abstract}
The course "Tourism, Mountaineering and Orienteering" (TMO) includes lots of situations which provoke high psychic tension, anxiety and stress. This study aims at revealing the influence of self-control skills on students' anxiety (trait and state), the perceived stress and psychic well-being during TMO course.

Methods: Perceived Stress Scale (PS-1); State-Trait Anxiety Inventory (STAI); Scale for measurement of the level of selfcontrol developed; The well-being index (WHO-5). There was a single research on self-control. The other variables were researched at the beginning and at the end of the course.

Results: The comparative analysis of the empirical data (beginning-end of the course) showed that state anxiety and perceived stress decreased, and well-being increased. There were no statistically significant differences as regards trait anxiety. Self-control had a great impact on perceived stress $(\beta=-0.46)$; trait anxiety $(\beta=-0.26)$; state anxiety $(\beta=-0.21)$ and psychic well-being $(\beta=0.37)$.

Discussion and conclusion: Students' expectations as regards TMO course are related to experiencing difficulties, dangerous situations and uncertainty which leads to their involvement in it with marked anxiety, uneasiness, and stress. Students' participation and completion of TMO course leads to changes in their attitude towards its contents, degree of experienced stress and danger which is justified by the obtained results from the second study.
\end{abstract}

Key words: trait, state anxiety, well-being

\section{INTRODUCTION}

The course "Tourism, Mountaineering and Orienteering", takes an essential part in the educational process of the students from the National Sports Academy. The required situations and tasks in the educational program during the course, linked with each of the individual strands, are specific with a high degree of difficulty and extremity. They contain a lot of factors that define them as stressful. Moreover, a lot of unforeseen circumstances could influence the extremity of the TMO course - a change in the meteorological conditions - rain, storm, fog and darkness. The new and unexpected, and the lack of experience may provoke embarrassment, anxiety, anguish and stress (Shopov, Valtchev, 2015). According to our observations, these psychological states of mind are specific for most of them, before the beginning of the educational activities. Throughout the course, the students achieve more self-confidence and there is a considerable drop of the negative psychological state by the end of the course - positivity, satisfaction and confidence are predominant, which come from the obtained knowledge and skills (Pavlov,
Zhelyazkov, 2013).

We assume that the negative psychological states of the students, relating to the course TMO, are a result of their expectations that the courses will have a higher level of difficulty. The lack of knowledge and experience in the area of tourism, mountaineering and orienteering, is a reason for their inadequate expectations and psychological states. Some of the popular psychological constructs are stress and anxiety.

Stress is one of the most important psychological constructs in behavior science and that's why there are many approaches to its study. The interactive approach defines stress as lack of balance between the demands of the environment and the individual abilities to cope, i.e. the level of stress is function of the ability of a person to answer the requirements of a given situation (Martens, et al., 1990).

Stress has become an inseparable part of human life and can be observed in every sphere of life. Regardless of the huge interest towards stress, due to the complexity and multifaceted nature of the surveyed phenomenon, and the different theoretical orientations of its researchers, there is no stan- 
dardized concept on stress and its nature, specifics, mechanisms of formation and functioning. The representatives of the divergent strands in the different areas of scientific research give a specific interpretation of its gist and functional characteristics.

Anxiety is a basic component of stress and it is not only a symptom or manifestation of stress, but also a cause of further stress.

Anxiety is a basic component of stress and it is not only a symptom or manifestation of stress, but also a cause of further stress. One of the most popular theories, a base of a number of surveys, outlines two types of anxiety - trait and state anxiety (Spielberg, 1983). Trait anxiety is viewed as a stable, acquired behavior disposition, personality trait which predisposes to perceiving a wide range of objectively safe stimuli as threatening ones and to reaction involving state anxiety, which significantly exceeds the objectively normal one.

State anxiety refers to the dynamic psychic conditions. It appears when an individual perceives a certain irritant or situation as including some actual or potential elements of danger, threat or harm. In the context of the concept of the genesis of stress, state anxiety is viewed as a function of the correlation between a certain need and the possibilities for its satisfaction. The lower probability of satisfying a need, combined with a high need, determined by inner or outer factors, lead to the manifestation of increased state anxiety (Spielberg, 1983). Anxiety, as a personality trait, affects performance. Individuals with low trait anxiety and high state anxiety find it easier to reach top achievement, while individuals with high trait and state anxiety have worse sports performance.

Anxiety and cumulated stress are often a result of the individual skill of self-control. Self-control is the behavioral conduct in a situation of high levels of psychological pressure and stress. A conduct, leading to a change into the level of control over the situation (Rosenbaum, 1989; 1990). The self-control skills include:

- knowledge of different methods for coping with the emotional and physiological reactions;

- application of solution strategies (planning, defining the problems research and comparison of the alternatives, foreseeing of the consequences);

- ability to postpone an immediate advantage;

- a basic confidence in the own capabilities for inner self-regulation of the events.

The term well-being encompasses all the ways in which people experience and evaluate their lives positively. Psychic well-being includes components referring to cognitive and affective aspects: life satisfaction and presence of positive and negative emotions in one's life, and a subjective feeling of happiness (Topp et all., 2015; Tov, 2018).

The present research is directed towards the unveiling of the dynamics of the psychological conditions in the TMO course and the influence of the self-control skills over it. We could assume that in the beginning of the course the students suffer a higher trait and state anxiety and increased levels of stress. Following the theoretical preparations and the acquired experience after their inclusion in different situations, by the end of the course, the levels of these conditions are considerably lowered. However, self-control skills have a great influence over the dynamics of these psychological conditions.

Aim of the research: to be determined the dynamics of the psychological conditions in the course TMO and the influence of the self-control skills over it. Tasks of the research:

- to be determined the levels of trait and state anxiety, accumulated stress and psychological well-being of the students from NSA in the beginning and in the end of the course TMO;

- to be determined the dynamics of these variables;

- to be determined whether the changes between the beginning and the end of the course are significant;

- to establish whether there is a difference in the dynamics of the factors sex, form of education or type of sport;

- to unveil the influence of the self-control skills over the dynamics of the researched psychological states.

\section{METHODOLOGY}

Participants: For the realization of this research there have been formed four groups of 50 students each. Two groups, consisting of part-time university students, and two groups - full-time university students.

Procedure: There have been applied specialized tests for research and examination of the psychological state of the participants in the course. There 
has been designed and constructed a specialized topographic card with the software product OCAD 12. Throughout the activities there were used individual location systems. There has been performed a topographic training with the students as well as theoretical and practical training on orienteering and mountaineering.

For a better assessment of the dynamics of the psychological states, there have been undertaken double examinations - at the beginning and in the end of the course. Subject of the surveys is the level of undertaken stress, trait and state anxiety and well-being.

\section{Research methods:}

1. WHO-5, Well-being Index - short questionnaire covering 5 positively items, related to positive mood, vitality, and general interests (being interested in things). Each of the five items is rated on a 6-point Likert scale from 0 ( $=$ not present) to 5 (= constantly present). Scores are summated, with raw score ranging from 0 to 25 . Then the scores are transformed to $0-100$ by multiplying by 4 , with higher scores meaning better well-being (https://www.psykiatri-regionh.dk/who-5/who-5-questionnaires/Pages/ default.aspx).

2. Questionnaire for perceived stress (PS-1) (Cohen, Kamarck, Mermelstein, 1983) and adapted for Bulgarian conditions (Karastoyanov, Russinova, 2000). It consists of 7 positively and 7 negatively formulated items. The researched people have to evaluate from 1 to 5 the frequency of their feelings and thoughts described by the items. The results characterize a relatively stable evaluation style for a given period of time.
3. State-Trait Anxiety Inventory (STAI) (Spielberger, 1983) is a self-reported instrument. It was designed to assess levels of state anxiety and traint anxiety, through 40 items. All items are rated on a 4-point scale (e.g., from "Almost Never" to "Almost Always"). Higher scores indicate greater anxiety. State anxiety can be defined as a transient momentary emotional status that results from situational stress. Trait anxiety represents a predisposition to react with anxiety in stressful situations. This data set includes two STAI subscale score. Anxiety Form Y, its most popular version, has 20 items for assessing trait anxiety and 20 for state anxiety. The questionnaire was adapted for Bulgarian conditions (Shtetinski, Paspalanov, 1989).

4. Scale for measurement of the level of self-control developed by Rosenbaum (1990) and adapted for Bulgarian conditions (Georgiev, 2001). The test consists of 36 statements and a 6-stage scale of a Likert type for evaluation of each one of the statements. The higher the score is, the better the self-control skills.

The statistical processing of the empirical data includes a variational analysis and a comparative analysis - Mann-Whitney - U nonparametric criteria and Bayes Factor for corelated samples - $\mathrm{T}$ Test.

The results from the variational analysis of the surveyed variables show that the state anxiety, trait anxiety and perceived stress have higher levels in the beginning of the course. In the opposite, well-being has higher levels at the end of the course (fig. 1). The established levels of the variables in the beginning and in the end of the course have close values. To establish whether the observed differences are significant for the research, a comparative analysis has been undertaken.

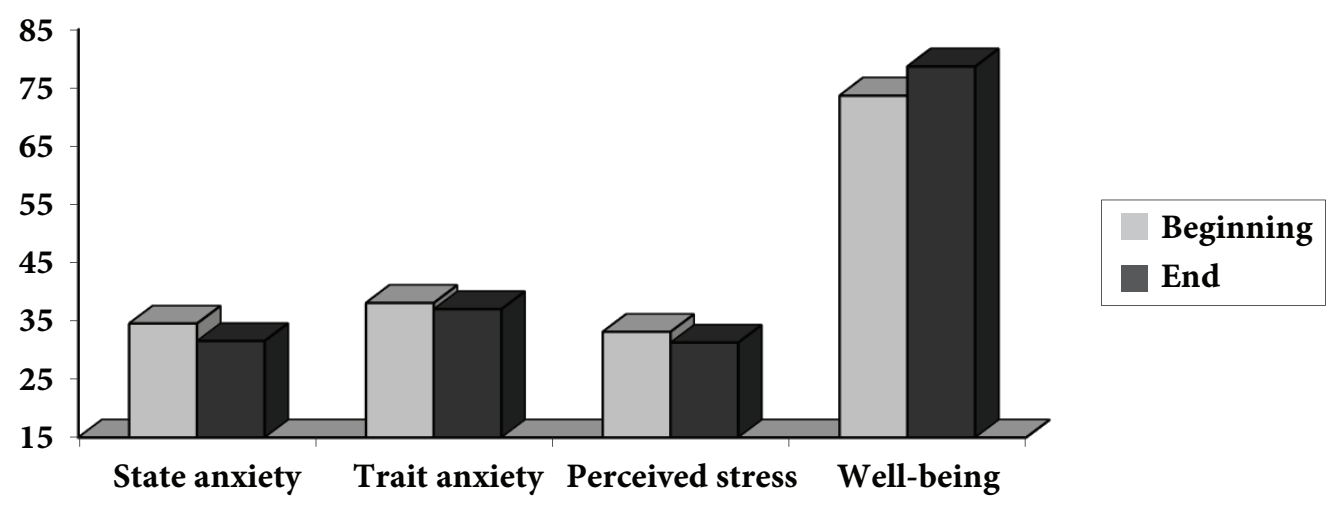

Figure 1. Average values of the researched variables in the beginning and in the end of course TMO. 
The comparative analysis has been realized in a traditional way, based on the frequency statistics (Wilcoxon - T) and on the basis of Bayes statistics (Bayes Factor - T Test) as well.

The results of the comparative analysis by the Wilcoxon criterion lead to the conclusion that considerable changes have occurred in each of the four examined variables. All of them show predominant differences at the level of importance $\rho=0.01$ (Table 1 ).

The second approach for comparative analysis (Bayes Factor) has helped to establish similar results, excluding trait anxiety, where no statistically meaningful differences have been made between the first and the second measurement (Table 2). This result confirms what has been established after series of researches: trait anxiety, as a trait of personality, is relatively sustainable, and if it changes, that happens under the influence of many factors, which influence the personality through long periods of time. The course TMO has a relatively short duration and cannot influence considerably that variable.

Table 1. Results from the comparative analysis of the examined variables before and in the end of the course TMO (Wilcoxon)

\begin{tabular}{|l|c|c|c|c|}
\hline & State anxiety & Trait anxiety & Perceived stress & Well-being \\
\hline $\mathrm{T}$ & -5.247 & -3.011 & -3.776 & -3.297 \\
\hline Asymp. Sig. & .000 & .003 & .000 & .001 \\
\hline
\end{tabular}

Table 2. Results from the comparative analysis of the examined variables before and in the end of the course TMO (Bayes Factor)

\begin{tabular}{|l|r|r|r|r|}
\hline & Bayes Factor & \multicolumn{1}{c|}{ t } & \multicolumn{1}{c|}{ df } & \multicolumn{1}{c|}{ Sig. (2-tailed) } \\
\hline State anxiety & .113 & 3.165 & 102 & .002 \\
\hline Trait anxiety & 7.606 & 1.031 & 102 & .305 \\
\hline Perceived stress & .014 & 3.831 & 102 & .000 \\
\hline Well-being & .410 & -2.681 & 101 & .009 \\
\hline
\end{tabular}

In order to reveal the specifics of the researched course are provoked by the difficulties, dangerous variables in relation with the factors sex, type of situations and uncertainty, which lead to their parsport and type of education, a comparative analy- ticipation in the activities with high levels of trousis has been done by using two and more than two ble, anxiety, and stress. It has been established that non-biased samples. The results from the analysis state, trait anxiety and the stress felt, reach higher show no considerable differences in the beginning levels in the beginning of the course. The particiand in the end of the course as well. This leads us pation in the course TMO and its completion lead to the assumption that the researched students are to a change in the students 'attitude towards its characterized by similar levels and dynamics of the content, level of stressogenic factors and danger, for variables under research.

The assumption that self-control skills influence the anxiety, cumulated stress and well-being leads us to a regression analysis. The results from the analysis give the reason to believe that high levels of self-control skills lead to a decrease of state anxiety $(\beta=-0.374)$, of trait anxiety $(\beta=-0.379)$, and the levels of cumulated stress $(\beta=-0.50)$ and to an increase in well-being $(\beta=0.371)$. People with higher self-control skills use a more rational cognitive and behavioral strategies to cope with difficult situations in the course TMO.

\section{DISCUSSION AND CONCLUSION}

The students' expectations, concerning the TMO which testify the results achieved from the second research.

The data from the twofold research of psychic well-being show that its level at the end of the course TMO is statistically significantly higher than the recorded level at the beginning of the training process.

The high levels of self-control skills lead to a significant increase in the well-being and a decrease in trait and state anxiety and cumulated stress

The obtained results and the subsequent conclusions will be used to optimize the methodology of the education in tourism, mountaineering and 
orienteering in the university courses and to enrich the psychological approach to the students in the

\section{REFERENCES}

Cohen, S. and Williamson, G. (1988). Perceived Stress in a Probability Sample of the US. In: Spacapam, S. and Oskamp, S., Eds., The Social Psychology of Health: Claremont Symposium on Applied Social Psychology, Sage, Newbury Park.

Cohen, S., Kamarck, T., \& Mermelstein, R. (1983). A global measure of perceived stress. Journal of Health and Social Behavior, 24(4), pp. 385-396.

Georgiev, M. (2001). SCS - skala za samokontrol - sashtnost i nasoki za prilozhenie. - V: Lichnost, motivatsia, sport. T. 6 - pod nauchn. redaktsia na N. Popov. NSA - Pres, S. // Георгиев, M. SCS - скала за самоконтрол - същност и насоки за приложение. - В: Личност, мотивация, спорт. Т. 6 - под научн. редакция на Н. Попов. НСА - Прес, С., 2001

Karastoyanov, G., Rusinova-Hristova, A. (2000). Balgarska adaptatsia na vaprosnika za vazpriet stres. V: Psihologichni izsledvania, kn. 1- 2, S. // Карастоянов, Г., Русинова-Христова, А. 2000. Българска адаптация на въпросника за възприет стрес. В: Психологични изследвания, кн. 1- 2, С.

Pavlov, D., Zhelyazkov St. (2015). Promeni vav funktsionalnoto sastoyanie na studentite uchastnitsi v uchebnite kursove po „TAO” pri NSA „Vasil Levski“. - Nauchna konferentsia „Evropeyski standarti v sportnoto obrazovanie" - Vratsa 2013 g. // Павлов, Д., Желязков, Ст. (2013). Промени във функционалното състояние на студентите участници в учебните курсове по „ТАО“ при НСА „Васил Левски“. - Научна конференция „Европейски стандарти в спортното образование” Bраuза 2013 г.

Rosenbaum, M. (1989). Self-Control under stress: The role of learned resourcefulness. Adv. Behav. Res. Ther. 11 pp.249-258

Rosenbaum, M. (1990). Learned resourcefulness. On Coping Skills, Self-Control, and Adaptive Behavior. N.Y

Shopov, A., Valchev, V. (2015). Vliyanie na nadmorskata visochina varhu saturatsiyata i pulsa pri studenti zadochno obuchenie (2013-2014 g.) Sport \& Nauka, S. // Шо- beginning of the course.

пов, А., Вълчев, В. (2015). Влияние на надморската височина върху сатурацията и пулса при студенти задочно обучение (2013-2014 г.) Спорт \& Наука, С.

Shtetinski, D., Paspalanov, I. (1989). Metodichesko posobie za rabota s bylgarskata forma na vyprosnika za ocenka na trevozhnostta na Ch. Spilbargar. // Щетински, Д., Паспаланов, И. (1989). Методическо пособие за работа с българската форма на въпросника за оценка на тревожността на Ч. Спилбъргър. С.

Spielberger, C.D. (1983). State-Trait Anxiety Inventory STAI. Consulting Psychologists Press, Palo Alto.

Temp, A.G.M., Lee, B., Bak, T.H. (2017). Well-Being at the Polish Polar Station, Svalbard: Adaptation to Extreme Environments. In: Latola K., Savela H. (eds) The Interconnected Arctic - UArctic Congress 2016. Springer Polar Sciences. Springer, Cham

Topp, C.W., Østergaard, S.D., Søndergaard, S., \& Bech, P. (2015). The WHO-5 Well-Being Index: A Systematic Review of the Literature. Psychotherapy and Psychosomatics, 84, pp. 167-176.

Tov, W. (2018). Well-being concepts and components. In E. Diener, S. Oishi, \& L. Tay (Eds.), Handbook of well-being. Salt Lake City, UT: DEF Publishers. DOI: nobascholar.com

WHO. (1998). Wellbeing Measures in Primary Health Care/The Depcare Project. WHO Regional Office for Europe: Copenhagen.

WHO-5 Questionnaires. https://www.psykiatri-regionh. $\mathrm{dk} /$ who-5/who-5-questionnaires/Pages/default.aspx (accessed on 10th december 2019)

\section{Corresponding author:}

Galina Domuschieva-Rogleva,

National Sports Academy "Vassil Levski",

Department "Psychology, Pedagogy and Sociology",

21 Acad. Stefan Mladenov str., Bulgaria, Sofia 1700,

E-mail: galinarogleva@abv.bg 